\title{
STATUS DAN KEDUDUKAN HUKUM LEMBAGA FINANCIAL TECHNOLOGY (FINTECH) SYARIAH DALAM MENYELENGGARAKAN JASA KEUANGAN KEPADA MASYARAKAT
}

\author{
Raden Siti Sumartini \\ Jajang Arifin \\ Stefani Gatri Sagala \\ Universitas Wiralodra \\ Email: sitisumartini2020@gmail.com, jajangarifincyber@ gmail.com, \\ stevanigatri11@gmail.com,
}

\begin{abstract}
The development and enthusiasm of the community towards the growth of sharia economic practices is very high, especially with the proliferation of the establishment of sharia financial institutions (LKS), one of which is sharia fintech. Sharia fintech is an innovation of sharia-based financial services by utilizing technological advances. In addition to providing offers and schemes that are different from conventional services, it also provides certain limitations on the use of funds provided by investors or lenders. In addition, the development of sharia fintech needs to be supported by the appropriate regulations and infrastructure. With the support for these two aspects, the actors and service users of Islamic financial institutions will have the convenience of meeting the needs of financial access. Access to these financial needs in its development has become increasingly complex and diverse. In this case, the author conducted research using normative juridical methods. This juridical approach is because this research analyzes existing legal aspects, and is normative because this research focuses more on the analysis of existing laws and regulations and other regulations, using secondary data, namely scientific references or other scientific papers as study material that can support the completeness of this scientific work. The phenomenon of disruptive innovation that occurs in the financial services industry such as the emergence of fintech has great potential because it can provide solutions to urgent needs that traditional financial institutions cannot provide. Fintech refers to the use of technology to provide financial solutions. Although it is relatively new, Islamic fintech does not have a significant difference with conventional fintech. Because both types want to provide financial services. The difference between the two is only a financing contract which follows the rules of Islamic law. There are three sharia principles that must be owned by this fintech, namely no maisir (betting), gharar (uncertainty) and usury (the amount of interest past the stipulation.
\end{abstract}

\section{Keywords: Sharia Financial Technology, Consumer Protection and Financial Services} Authority

\section{PENDAHULUAN}

Saat ini perkembangan teknologi dan internet sudah sangat pesat, semua sudah dibuat menjadi lebih mudah. Salah satu sektor yang terpengaruh oleh perkembangan 
teknologi informasi dan komunikasi adalah perbankan dan juga pada sektor jasa keuangan lainnya, sub sektor ekonomi yang memobilisasi dana masyarakat. Teknologi informasi dan komunikasi telah melahirkan inovasi perbankan serta memberikan dampak efisien dan ektivitas yang luar biasa ${ }^{1}$.

Demikian selanjutnya perkembangan teknologi berdampak bagi aspek kehidupan ekonomi masyarakat. Munculnya financial teknologi (selanjutnya disebut fintech syariah) berbasis syariah memberikan kemudahan untuk mendapatkan dana yang diinginkan dengan waktu yang singkat dan mudah prosesnya. Dalam menggunakan layanan fintech syariah memiliki kemudahan yaitu antara penerima pinjaman atau pembiayaan tidak perlu bertatap muka langsung dan kebutuhan finansial lebih mudah terpenuhi serta sebagaimana umat muslim yaitu melakukan kegiatan keuangan bersadasarkan syariah Islam².

Adapun finansial technologi syariah (fintech syariah) hadir di Indonesia karena custommers segmentation (segmen pasar) serta membawa misi, yaitu mengupayakan solusi dari masalah finansial yang terjadi di masyarakat. Akan tetapi, misi tersebut terganjal oleh regulasi hukum yang hampa sehingga belum dapat terwujud. Hal ini terjadi karena pertumbuhan fintech di Indonesia masih ada ketidak jelasan pemisahan antara aturan untuk fintech konvensional dan fintech syariah. Regulasi yang mengatur fintech saat ini yaitu Peraturan Otoritas Jasa Keuangan Nomor 77/POJK.01/2016 tentang Layanan Pinjam Meminjam Uang Berbasis Teknologi Informasi yang diterbitkan pada akhir Desember 2016 lalu. Namun demikian, peraturan tersebut hanya mengatur mengenai pembiayaan fintech dengan sistem konvensional dan belum mengatur sistem syariah yang saat ini juga sudah mulai berkembang ${ }^{3}$.

Di dalam dasar pertimbangan regulasi yang mengatur tentang lembaga Otoritas Jasa Keuangan dijelaskan untuk mewujudkan perekonomian nasional yang mampu tumbuh secara berkelanjutan dan stabil, diperlukan kegiatan di dalam sektor jasa keuangan yang terselenggara secara teratur, adil, transparan, dan akuntabel, serta mampu mewujudkan sistem keuangan yang tumbuh secara berkelanjutan dan stabil, dan mampu melindungi kepentingan konsumen dan masyarakat. Adapun lembaga Otoritas Jasa Keuangan (OJK)

${ }^{1}$ Resa Raditio, Aspek Hukum Transaksi Elektronik, Jakarta, Graha Ilmu, 2014, hlm. 65.

${ }^{2}$ Lihat dalam Raden Ani Eko Wahyuni, "Perkembangan Ekonomi Islam di Indonesia Melalui Penyelenggaraan Fintech Syariah" Jurnal Kajian Hukum Islam, Vol. 4, No. 2, Desember 2019, hlm. 184.

3 Maulana Reyza Alfarisi, Muhammad Waliyam Mursida, Moch. Irfan Dwi Syahroni "Model Regulasi Financial Technology Syariah Dalam Kerangka Hukum Indonesia, Studi Perbandingan Malaysia dan Inggris," Legeslatif, Vol. 3 No.1 Desember 2019, hlm. 73-74. 


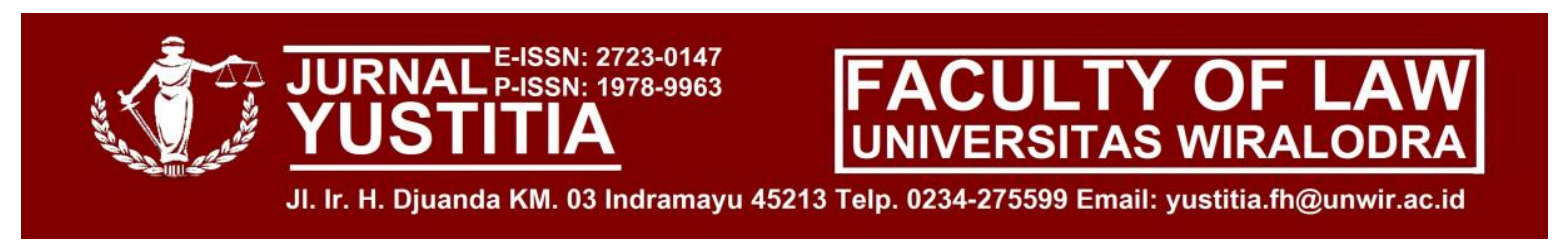

sendiri adalah adalah lembaga yang independen dan bebas dari campur tangan pihak lain, yang mempunyai fungsi, tugas, dan wewenang pengaturan, pengawasan, pemeriksaan, dan penyidikan ${ }^{4}$.

Disamping itu perkembangan fintech syariah perlu didukung oleh regulasi dan infrastruktur yang tepat. Dengan adanya dukungan atas dua aspek tersebut, para pelaku dan pengguna jasa lembaga keuangan syariah akan mendapat kemudahan untuk memenuhi kebutuhan financial access 5 . Kebutuhan financial aksse tersebut dalam perkembangannya telah semakin kompleks dan beragam ${ }^{6}$. Pada sisi lain, gagasan penerapan fintech syariah ini mempertimbangkan regulasi yang belum teridentifikasi secara tegas sebagai pembeda yang signifikan dengan praktik lembaga keuangan konvensional.

Antusiasme masyarakat terhadap pertumbuhan praktek ekonomi syariah sangat tinggi, terlebih dengan menjamurnya pendirian lembaga keuangan syariah (LKS) salah satunya adalah fintech syariah. Fintech syariah merupakan inovasi layanan keuangan berbasis syariah dengan memanfaatkan kemajuan teknologi. Selain memberikan penawaran dan skema yang berbeda dari layanan konvensional, juga memberikan batasan tertentu terhadap penggunaan dana yang di berikan oleh investor atau pemberi pinjaman ${ }^{7}$.

Beberapa regulasi yang mengatur fintech saat ini Peraturan Otoritas Jasa Keuangan Nomor 77/POJK.01/2016 tentang Layanan Pinjam Meminjam Uang Berbasis Teknologi Informasi yang diterbitkan pada akhir Desember 2016 dan dihubungkan dengan Selain itu berkenaan dengan fintech syariah, Majelis Ulama Indonesia juga telah mengeluarkan fatwa Dewan Syariah Nasional Majelis Ulama Indonesia No: 116/DSN-MUI/IX/20I7 Tentang Uang Elektronik Syariah yang mana mencantumkan tentang Ketentuan Biaya Layanan Fasilitas $^{8}$. Disamping itu di dukung juga dengan fatwa Dewan Syariah Nasional Majelis Ulama Indonesia Nomor: 117/DSN-MUI/II/2018 yakni Tentang Layanan Pembiayaan Berbasis Teknologi Informasi Berdasarkan Prinsip Syariah ${ }^{9}$. Selanjutnya didalam

\footnotetext{
4 Pasal 1 Undang-Undang No. 21 Tahun 2011 tentang Otoritas Jasa Keuangan.

5 Penelope H. Financial Access and Financial Stability, BIS Working Papers, May, 2011, hlm. 67, menjelaskan bahwa sistem akses keuangan terdiri dari sejumlah komponen yang saling terkait -infrastruktur (termasuk sistem hukum, pembayaran, penyelesaian dan akuntansi), pasar (saham, obligasi, uang, dan derivatif) dan institusi (bank, perusahaan sekuritas dan investor institusi).

6 Firdaus F, F, A. Faiqoh Silvana, "Ketegasan Regulasi Laporan Ketaatan Syariah dalam optimalisaisi Financial Technology Lembaga Keuangan Syariah", Perisai, Vol. 1, No. 3, October 2017, hlm. 49-94.

7 Raden Ani Eko Waluyo, Ibid, hlm. 185.

8 Fatwa DSN Majelis Ulama Indonesia No: 116/DSN-MUI/IX/20I7 Tentang Uang Elektronik Syariah

9 Fatwa DSN MUI No: 117/DSN-MUI/II/2018 Tentang Layanan Pembiayaan Berbasis Teknologi Informasi Berdasarkan Prinsip Syariah.
} 


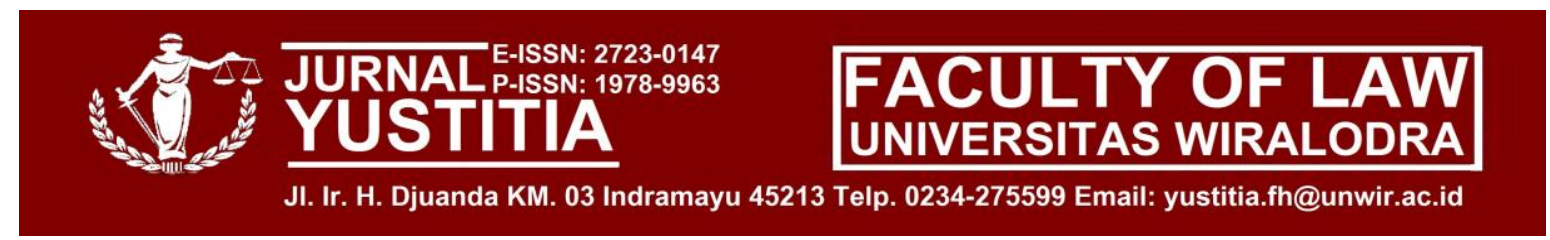

memberikan pelayanan pelayanan kepada nasabah atau konsumen fintech syariah ini juga harus mengacu kepada Pasal 4 huruf C Undang-Undang No 21 Tahun tahun 2011 tentang Otoritas Jasa Keuangan ${ }^{10}$.

\section{IDENTIFIKASI MASALAH}

Berdasarkan pemaparan dari latar belakang tersebut dalam hal ini dapat diinventarisir persoalan persolan hukum yang terkait dengan perlnidungan konsumen dalam pelaksanaan finansial technologi syariah yang dihubungkan dengan peraturan peraturan yang terkait dengan Fintech Syariah tersebut, yani sebagai berikut:

1. Bagaimanakah Status dan Kedudukan Hukum Lembaga Finacial Technology (Fintech) Syariah Dalam Sektor Jasa Keuangan saat ini?

2. Bagaimanakah Bentuk Perlindungan Hukum Nasabah sebagai Konsumen Dalam Kegiatan Fintech Syariah Dihubungkan dengan Pasal 4 huruf (c) Undang-Undang No 21 Tahun 2011 Tentang Otoritas Jasa Keuangan?

\section{METODE}

Metode yang digunakan dalam Penelitian ini, meggunakan metode yuridis normatif. Pendekatan yuridis ini adalah karena penelitian ini dengan menganalisa aspek-aspek hukum yang ada, dan bersifat normatif karena penelitian ini lebih menitik beratkan pada analisa dari peraturan perundang-undangan yang ada dan peraturan lainnya, dengan menggunakan datadata sekunder yakni referensi-referensi ilmiah atau tulisan-tulisan ilmiah lainnya sebagai bahan kajian yang dapat mendukung kelengkapan karya ilmiah ini.

\section{HASIL DAN PEMBAHASAN}

Fintech syariah saat ini telah menjadi suatu alternatif di dalam lalu lintas keuangan non perbankan. Lahirnya lembaga fintech syariah tersebut karena kebutuhan dalam tuntutan pelayanan dalam lalu lintas keuangan yang menuntut serba cepat, efektif dan memliki prinsip syaraiah yang merupakan rujukan serta diharapkan dapat menghilangkan praktek praktek riba yang dilarang oleh agama. Disamping itu sebagai suatu bentuk negara hukum kesejahteraan yang dalam hal ini tertuang di dalam pembukaan Undang-Undang Dasar Tahun 1945 Undang-Undang Dasar Tahun 1945 juga telah memberikan suatu kerangka

\footnotetext{
${ }^{10}$ Undang-Undang Nomor 21 Tahun 2011 tentang Otoritas Jasa Keuangan.
} 


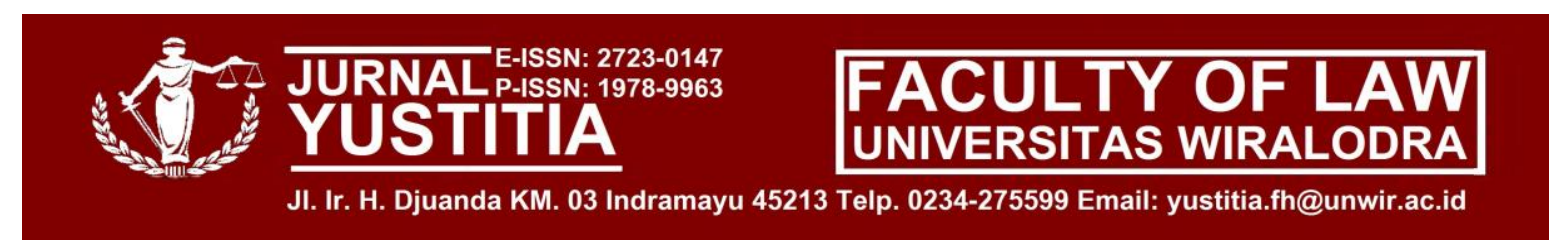

kebijakan dan arahan dalam menumbuhkembangkan sector ekonomi khusunya sector keuangan non perbankan. Hal tersebut di perjelas dalam Pasal 33 ayat (4) Undang-Undang dasar Tahun 1945 yang menjelaskan bahwasannya perekonomian nasional diselenggarakan berdasar atas demokrasi ekonomi dengan prinsip kebersamaan, efesiensi berkeadilan, berkelanjutan, berwawasan lingkungan, kemandirian serta dengan menjaga kemajuan dan kesatuan ekonomi nasional. Demikian selanjutnya membangun suatu negara yang kuat juga memerlukan akumulasi kekayaan dan kapital, oleh karenanya pembangunan ekonomi harus diprioritaskan ${ }^{11}$.

Selanjutnya Negara Indonesia merupakan negara hukum yang memiliki perhatian besar pada pertumbuhan perekonomian. Pertumbuhan ekonomi suatu bangsa memerlukan suatu sistem pengaturan ekonomi tersedia terarah serta terpadu yang kemudian dimamfaatkan untuk peningkatan kesejahteraan rakyat. Lembaga-lembaga keuangan bahumembahu mengelola dan menggerakan semua potensi ekonomi agar berdaya supaya lebih berhasil secara optimal. Indonesia merupakan negara dengan jumlah penduduk muslim terbanyak di dunia. Oleh karenanya dalam hal ini Indonesia juga berpeluang untuk menjadi negara dengan perkembangan nilai asset ekonomi syariah tertinggi di dunia ${ }^{12}$.

\section{Status dan Kedudukan Hukum Lembaga Finacial Technology (Fintech) Syariah Dalam Sektor Jasa Keuangan}

Pada era teknologi yang begitu cepat dan massive saat ini perkembangan teknologi sedemikian rupa dapat dipastikan memberikan efek resiko cukup tinggi jika tidak dimanfaatkan dengan baik. Dengan adanya teknologi, pemanfaatan terhadap pengelolaan sumber daya alam cukup mudah dan efisien. Masyarakat saat ini telah banyak terpengaruhi dengan adanya percepatan teknologi saat ini, beragam informasi yang didapat dari berbagai fitur menarik dalam tiap gadget (telepon genggam) individu. Hingga, perilaku masyarakat saat ini sangat berubah secara signifikan.

Selanjutnya perkembangan teknologi yang saat ini menjadi pembahasan yang begitu hangat (trend) di Indonesia adalah Teknologi Finansial atau disebut (Fintech). Menurut

\footnotetext{
${ }^{11}$ Hata, Hukum Perdagangan Internasional Dalam Sistem GATT dan WTO, Bandung, Refika Aditama, 2006, hlm. 28.

${ }^{12}$ Yayat Rahmat Hidayat, Analisis Peluang Dan Tantangan Lembaga Keuangan Syariah Untuk Meni-ngkatkan Daya Saing Menghadapi Masyarakat Ekonomi Asean. Amwaluna: Jurnal Ekonomi Dan Keunangan Syariah, Vol. 2, Nomor.2, 2018, hlm. 14.
} 
definisi yang dijabarkan oleh lembaga Bank Indonesia, hasil gabungan antara jasa keuangan dengan teknologi yang mengubah model konvensional menjadi lebih moderat. Saat ini, masyarakat cenderung menyukai terhadap segala sesuatu yang praktis, instan, lebih cepat dan fleksibel. Pada abad ke-21 menjadi tahun metamorfosis yang berkesinambungan, dimana perubahan yang menonjol dari hal teknologi dan gaya hidup (lifestyle $)^{13}$.

Teknologi keuangan atau Fintech adalah suatu kesempatan yang sangat potensial. Dilihat dari aspek letak geografis yang luas, bisa juga dilihat dari pertumbuhan kelas menengah yang tinggi, sehingga penetrasi produk keuangan yang besar bergabung dalam membuat pasar yang kuat dalam pengembangan fintech di Indonesia. Dengan hanya 36\% dari populasi yang mempunyai rekening bank, fintech di Indonesia menawarkan layanan keuangan yang dapat digunakan kepada penduduk yang belum tersentuh oleh perbankan (unbankable) (Aam, 2019) ${ }^{14}$. fenomena inovasi disruptif (Disruptive Innovation) yang terjadi di Industri Jasa Keuangan seperti munculnya fintech ini memiliki potensi besar karena dapat memberikan solusi untuk kebutuhan mendesak yang tidak dapat disediakan oleh lembaga keuangan tradisional. Fintech mengacu pada penggunaan teknologi untuk memberikan solusi keuangan ${ }^{15}$.

Financial Technology sistem syariah pertama kali hadir di Dubai, Uni Emirat Arab. Pada tahun 2014 silam, Beehive berhak mendapatkan sertifikat yang pertama dengan menggunakan pendekatan peer to peer lending marketplace. Hingga saat ini, Beehive menjadi salah satu lembaga teknologi keuangan terkemuka di dunia dengan cakupan pasar yang sangat luas. Berawal dari Beehive, fintech berbasis syariah pun menjalar ke negara Asia lainnya, semisal Singapura dan Malaysia ${ }^{16}$.

Sementara itu, di Indonesia kita mengentahui platform fintech di Indonesia secara umum tumbuh dengan pesat dari tahun 2015 hingga akhir $2017^{17}$. Dan sebagian besarnya berasaskan secara konvensional. Dalam perkembangannya Humayon Dar yang merupakan Direktur Jenderal Islamic Research \& Training Institute (IRTI) di Islamic Development

\footnotetext{
${ }^{13}$ Maziyah Mazza Basya dkk, "Strategi Pengembangan Fintech Syariah Dengan Pendekatan Business Model Canvas di Indonesia”, OECONOMICUS Journal Of Economics, Volume 4, No. 2, Juni 2020, hlm. 81.

${ }^{14}$ Idem

${ }^{15}$ Chuen, D.L.K., \& Teo, G.S. "Emergence of fintech and the LASIC principles". The Journal of Financial Perspectives: Fintech, winter, 2015, hlm. 24-37.

${ }^{16}$ Ahmat Parizi, Perkembangan Fintech Syariah, https://kseiprogres.com/perkembangan-fintech-syariah/ diakses pada tanggal 9 Agustus 2021.

${ }^{17}$ Hasan, S.M. Fintech in Indonesia: An Islamic outlook", 2018 article in http://ethiscrowd.com. Diakses pada tanggal 9 Agustus 2021.
} 


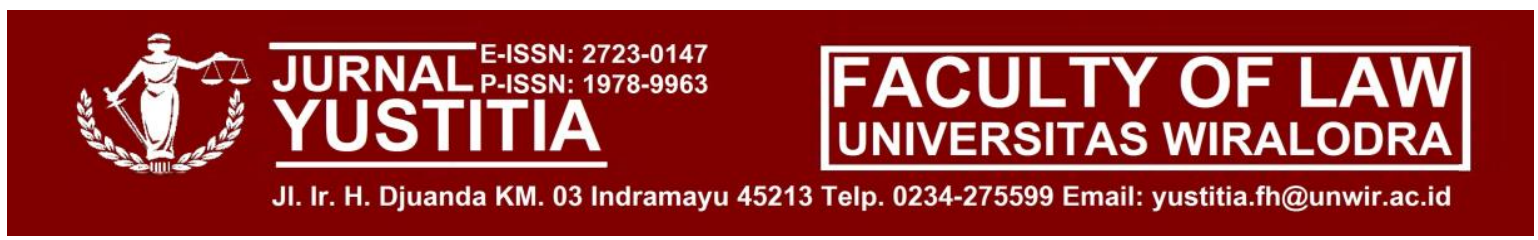

Bank (IDB) berkata nilai industri syariah secara global masih sangat kecil jika dibandingkan dengan industri konvensional. Namun pada tahun 2018, mulailah bermunculan beberapa fintech syariah yang diharapkan akan menjadi solusi berdasarkan hukum Islam. Tercatat ada 127 perusahaan yang mendaftarkan diri ke Otoritas Jasa Keuangan (OJK) data per 30 September 2019 yang mana terdiri dari 119 konvensional dan syariah. Walaupun begitu, baru ada sekitar 13 perusahaan saja yang memiliki izin di Indonesia, sedangkan sisanya tengah mengajukan surat konfirmasi tersebut kepada lembaga OJK. Kedepannya mungkin, keberadaan fintech syariah akan terus meningkat.

Demi tercapainya kepastian hukum dalam Financial Technology maka Bank Indonesia dan lembaga Otoritas Jasa Keuangan (OJK) harus memiliki peraturan yang mengatur Financial Technology secara spesifik agar dalam praktek Financial Technology memiliki kepastian hukum dan pengguna financial technology mengenai transaksi kredit memiliki perlindungan hukum yang melindungi para pengguna. Dihubungkan dengan Peraturan Otoritas Jasa Keuangan (POJK) maka peraturan yang diterbitkan oleh Otoritas Jasa Keuangan (OJK) harus memiliki kepastian hukum agar peraturan tersebut dapat berjalan dengan baik.

Menurut Peraturan Otoritas Jasa Keuangan Nomor 77/POJK.01/Tahun 2016. Selain itu berkenaan dengan fintech syariah, Majelis Ulama Indonesia juga telah mengeluarkan fatwa Dewan Syariah Nasional Majelis Ulama Indonesia No: 116/DSN-MUI/IX/20I7 Tentang Uang Elektronik Syariah yang mana mencantumkan tentang Ketentuan Biaya Layanan Fasilitas ${ }^{18}$. Disamping itu di dukung juga dengan fatwa Dewan Syariah Nasional Majelis Ulama Indonesia Nomor: 117/DSN-MUI/II/2018 yakni Tentang Layanan Pembiayaan Berbasis Teknologi Informasi berdasarkan prinsip syariah ${ }^{19}$.

Meski terbilang baru fintech syariah tidak memiliki perbedaan yang signifikan dengan fintech konvensional. Sebab, kedua jenis tersebut sama-sama ingin memberikan layanan keuangan. Perbedaan dari keduanya hanyalah akad pembiayaan saja yang mana mengikuti aturan-aturan dari syariat Islam. Ada tiga prinsip syariah yang harus dimiliki fintech ini yaitu tidak boleh maisir (bertaruh), gharar (ketidakpastian) dan riba (jumlah

\footnotetext{
${ }^{18}$ Fatwa DSN Majelis Ulama Indonesia No: 116/DSN-MUI/IX/20I7 Tentang Uang Elektronik Syariah.

${ }^{19}$ Fatwa DSN MUI No: 117/DSN-MUI/II/2018 Tentang Layanan Pembiayaan Berbasis Teknologi Informasi Berdasarkan Prinsip Syariah.
} 


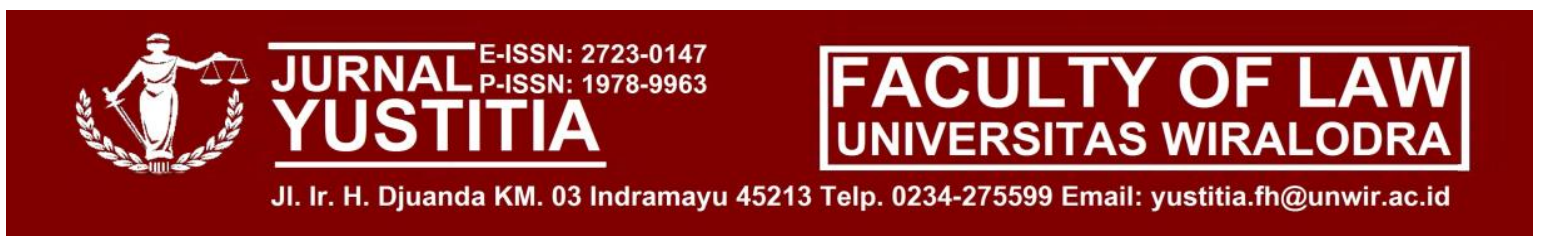

bunga melewati ketetapan). Walaupun menggunakan dasar syariah, rujukan dasar juga telah dibuat oleh Dewan Syariah Nasional terkait dengan keberadaan financial technology syariah ini. Dasarnya adalah MUI No.67/DSN-MUI/III/2008 yang mengatur tentang ketetapan apa saja yang harus diikuti lembaga teknologi keuangan terbaru di Indonesia tersebut ${ }^{20}$.

Dalam perkembangannya terdapat beberapa hal yang harus ditingkatkan dan dikembangkan dari perusahan-perusahan fintech di Indonesia, agar kualitas layanan kepada para klien dan nasabah semakin membaik. Langkah pertama yang dilakukan yaitu mengatasi masalah sumber daya manusia (SDM). Menurut Ajisatria, permasalahan SDM di lembaga Fintech disebabkan karena masih banyaknya pekerja di bidang keuangan yang belum memahami teknologi ${ }^{21}$ Dengan berbagai kelebihan yang dimiliki maka fintech syariah berpeluang untuk didorong sebagai ujung tombak pertumbuhan dan pengembangan industri keuangan syariah. Produk fintech syariah saat ini sudah begitu berkembang baik di dalam maupun di luar negeri seperti halnya payment solutions, remittances, wallets, crowdfunding, peer to peer lending, currency exchange, insurtech, dan artificial intelligence: robo advisers $^{22}$.

Namun pada sisi lain, terdapat beberapa tantangan dalam rangka mendorong fintech sebagai ujung tombak industri keuangan syariah. Beberapa tantangan yang menjadi catatan bersama bagi pelaku industri fintech syariah seperti menciptakan ekosistem fintech syariah yang memadai yang terintegrasi dan tercipta sinergi antara pemerintah, regulator, pelaku usaha fintech syariah, dunia pendidikan dan konsumen.

2. Bagaimanakah Bentuk Perlindungan Hukum Nasabah sebagai Konsumen Dalam Kegiatan Fintech Syariah Dihubungkan dengan Pasal 4 huruf (c) Undang-Undang No 21 Tahun 2011 Tentang Otoritas Jasa Keuangan

Perlindungan Hukum adalah hal yang mutlak harus tercipta sebagai bentuk perwujudan dari negara hukum. Dalam konteks kehidupan bernegara hukum adalah sarana atau alat untuk mengatur kepentingan sekaligus juga untuk memelihara agar ketertiban

\footnotetext{
${ }^{20}$ Ahmat Farizi, Loc.cit.

${ }^{21}$ Ferry Hendro Basuki1 dan Hartina Husein, “Analisis SWOT Financial Technology Pada Dunia Perbankan Di Kota Ambon (Survei Pada Bank di Kota Ambon), dalam Jurnal Manajemen dan Bisnis, Volume 2 No. 1 , 2018, hlm. 64

${ }^{22}$ Safri Haliding, Peluang, Tantangan dan Tata Kelola Fintech Syariah (artikel) https://www.medcom. id/ekonomi/analisa-ekonomi/9K5468Rk-peluang-tantangan-dan-tata-kelola-fintech-syariah diakses pada tanggal 22 Agustus 2021
} 


\section{TURNA-ISSN: 2723-0147}

masyarakat terjaga. Pemikiran konsep negara hukum sebenarnya sama tuanya dengan peradaban manusia itu sendiri.

Gagasan negara hukum telah dikemukakan oleh Plato, ketika ia mengintroduksi konsep Nomoi, sebagai karya tulis ketiga yang dibuat diusia tuanya, sementara itu dalam dua tulisan pertama, Politeia dan Politicous, belum muncul istilah negara hukum. Dalam Nomoi, Plato mengemukakan bahwa penyelenggaraan negara yang baik ialah yang didasarkan pada pengaturan (hukum) yang baik. Dalam bukunya Politicous yang dihasilkan dalam penghujung hidupnya Plato (429-347 SM) menguraikan bentuk-bentuk pemerintahan yang mungkin dijalankan. Pada dasarnya, ada dua macam pemerintahan yang dapat diselenggarakan; pemerintahan yang dibentuk melalui jalan hukum, dan pemerintahan yang terbentuk tidak melalui jalan hukum ${ }^{23}$.

Sebelum masuk kepada perlindungan konsumen pada sektor perbankan dan jasa keaungan pada umumnya di Indonesia, dalam hal ini terlebih dahulu akan diuraikan secara sekilas perkembangan permasalahan perlindungan konsumen sebelum dan sesudah berdirinya lembaga Otoritas Jasa keuangan (OJK). Dalam konteks hukum perbankan di Indonesia perihal perlunya perlindungan konsumen di sektor perbankan telah secara singkat disinggung dalam Undang-Undang Nomor 7 Tahun 1992 tentang Perbankan sebagaimana telah diubah dengan Undang-Undang Nomor 10 Tahun 1998 (selanjutnya disebut UU Perbankan).

Pengawasan dan pengaturan di sektor jasa keuangan sebelumnya berada di bawah otoritas Bank Indonesia yang mengatur dan mengawasi sektor perbankan, sedangkan Lembaga Keuangan Bukan Bank/LKBB atau sekarang dikenal dengan IKNB (Industri Keuangan NonBank) berada dalam pengawasan Departemen Keuangan cq. BAPEPAM-LK (Badan Pengawas Pasar Modal dan Lembaga Keuangan). Setelah dibentuknya lembaga Otoritas Jasa Keuangan OJK menjadikan pengaturan dan pengawasan sektor keuangan dilakukan secara terintegrasi ${ }^{24}$.

Berdasarkan ketentuan Pasal 4 huruf (C) telah dijelaskan bahwa lembaga Otoritas Jasa Keuangan terkait tujuan dibentuknya lembaga tersebut salah satunya adalah mampu melindungi kepentingan Konsumen dan masyarakat. Selanjutnya Pasal 55 Undang-Undang OJK tersebut, terhitung sejak tanggal 31 Desember 2012, fungsi, tugas, dan wewenang

\footnotetext{
${ }^{23}$ Ridwan HR, Hukum Administrasi Negara, Jakarta, Rajawali Press, 2010, hlm. 2.

${ }^{24}$ Ibid, hlm. 305.
} 
pengaturan dan pengawasan kegiatan jasa keuangan di sektor Pasar Modal, Perasuransian,

Dana Pensiun, Lembaga Pembiayaan, dan Lembaga Jasa Keuangan lainnya beralih dari Menteri Keuangan dan Badan Pengawas Pasar Modal dan Lembaga Keuangan pada lembaga OJK. Sedangkan untuk sektor perbankan terhitung sejak tanggal 31 Desember 2013, fungsi, tugas, dan wewenang pengaturan dan pengawasan kegiatan jasa keuangan di sektor Perbankan beralih dari Bank Indonesia ke lembaga OJK.

Untuk perlindungan konsumen dan masyarakat, Undang-Undang Republik Indonesia Nomor 21 Tahun 2011 Tentang Otoritas Jasa Keuangan pada Pasal 28 dan Pasal 29 menyebutkan bahwa OJK berwenang melakukan tindakan pencegahan kerugian konsumen dan masyarakat. Kewenangan OJK tersebut meliputi:

a. memberikan informasi dan edukasi kepada masyarakat atas karakteristik sektor jasa keuangan, layanan, dan produknya;

b. meminta Lembaga Jasa Keuangan untuk menghentikan kegiatannya apabila kegiatan tersebut berpotensi merugikan masyarakat; dan

c. tindakan lain yang dianggap perlu sesuai dengan ketentuan peraturan perundangundangan di sektor jasa keuangan.

Adapun ketentuan lainnya dalam aspek perlindungan konsumen dalam pelaksanaan jasa keaungan antara lain:

1. Pada Pasal 29 Undang-Undang Nomor 21 Tahun 2011 mengatur pelayanan pengaduan Konsumen oleh OJK. Pelayanan tersebut meliputi: menyiapkan perangkat yang memadai untuk pelayanan pengaduan Konsumen yang dirugikan oleh pelaku di Lembaga Jasa Keuangan; membuat mekanisme pengaduan Konsumen yang irugikan oleh pelaku di Lembaga Jasa Keuangan; dan memfasilitasi penyelesaian pengaduan Konsumen yang dirugikan oleh pelaku di Lembaga Jasa Keuangan sesuai dengan peraturan perundang-undangan di sektor jasa keuangan.

2. Sedangkan pada Pasal 30 mengatur perlindungan Konsumen oleh lembaga OJK dalam melakukan pembelaan hukum. Kewenangan OJK tersebut meliputi: mengajukan gugatan untuk memperoleh ganti kerugian dari pihak yang menyebabkan kerugian pada Konsumen dan/atau Lembaga Jasa Keuangan sebagai akibat dari pelanggaran atas peraturan perundang-undangan di sektor jasa keuangan. Sejak berfungsinya OJK, telah dikeluarkan sejumlah Peraturan dan Surat Edaran 
OJK yang terkait dengan perlindungan konsumen di sektor jasa keuangan, antara lain:

(1) Peraturan Otoritas Jasa Keuangan Nomor 1/POJK.07/2013 Tentang Perlindungan Konsumen Sektor Jasa Keuangan. Lembaran Negara Tahun 2013 Nomor 118, Tambahan Lembaran Negara Republik Indonesia Nomor 5431;

(2) Peraturan Otoritas Jasa Keuangan Nomor 1/POJK.07/2014 Tentang Lembaga Alternatif Penyelesaian Sengketa Di Sektor Jasa Keuangan. Lembaran Negara Tahun 2014 Nomor 12, Tambahan Lembaran Negara Republik Indonesia Nomor 5499;

(3) Surat Edaran Otoritas Jasa Keuangan Nomor 1/SEOJK.07/2014 Tentang Pelaksanaan Edukasi Dalam Rangka Meningkatkan Literasi Keuangan Kepada Konsumen Dan/Atau Masyarakat;

(4) Surat Edaran Otoritas Jasa Keuangan Nomor 2/SEOJK.07/2014 Tentang Pelayanan Dan Pengaduan Konsumen Pada Pelaku Jasa Keuangan;

(5) Surat Edaran Otoritas Jasa Keuangan Nomor 12/SEOJK.07/2014 Tentang Penyampaian Informasi Dalam Rangka Pemasaran Produk dan/atau Layanan Jasa Keuangan;

(6) Surat Edaran Otoritas Jasa Keuangan Nomor 13/SEOJK.07/2014 Tentang Perjanjian Baku; dan

Surat Edaran Otoritas Jasa Keuangan Nomor 7/SEOJK.07/2015 Tentang Pedoman Penilaian Lembaga Alternatif Penyelesaian Sengketa di Sektor Jasa Keuangan.

\section{PENUTUP}

\section{A. Simpulan}

1. Di dalam kerangka hukum positif Indonesia meski terbilang baru fintech syariah tidak memiliki perbedaan yang signifikan dengan fintech konvensional. Sebab, kedua jenis tersebut sama-sama ingin memberikan layanan keuangan. Perbedaan dari keduanya hanyalah akad pembiayaan saja yang mana mengikuti aturan-aturan dari syariat Islam. Ada tiga prinsip syariah yang harus dimiliki fintech ini yaitu tidak boleh maisir (bertaruh), gharar (ketidakpastian) dan riba (jumlah bunga melewati) 


\section{TURNATE-ISSN: 2723-0147 \\ JURNALP-ISSN: 1978-9963 \\ YUSTITIA}

2. Perlindungan Hukum adalah hal yang mutlak harus tercipta sebagai bentuk perwujudan dari negara hukum. Dalam konteks kehidupan bernegara hukum adalah sarana atau alat untuk mengatur kepentingan sekaligus juga untuk memelihara agar ketertiban masyarakat terjaga. Demikian juga di dalam pelaksanaan yang berkaitan dengan pelayanan lembaga fintech syariah ini juga penting adanya perlindungan hukum bagi konsumen (nasabah).

\section{B. Saran}

1. Lembaga Fintech Syariah dalam hal ini harus lebih dapat meningkatkan mutu pelayanan pada sector jasa keuangan, sehingga pada akhirnya mampu bersaing dengan lembaga-lembaga jasa keuangan lainnya baik perbankan maupun non bank.

2. Fintech Syariah juga harus memiliki perbedaan yang jelas dan tegas dengan lembaga jasa keuangan yang bersifat atau memiliki sistem konvensional.

\section{DAFTAR PUSTAKA}

\section{A. Buku :}

Ali Sakti, Ekonomi Islam: Jawaban Atas Kekacauan Ekonomi Modern, Yogyakarta: Pustaka Pelajar 2004;

Erman Rajagukguk, makalah "Pentingnya Hukum Perlindungn Konsumen Dalam Era perdagangan Bebas", dalam buku Hukum Perlindungan Konsumen, penyunting Husni Syawali dan Neni Sri Imaniyati, Bandung, Mandar Maju, 2000 ;

Hata, Hukum Perdagangan Internasional Dalam Sistem GATT dan WTO, Bandung, Refika Aditama, 2006;

Husni Syawali dan neni SriImaniyati, HukumPerlindungan Konsumen, Mandar Maju, Bandung, 2000;

Janus Sidabolak "Hukum Perlindungan Konsumen di Indonesia”Bandung, Citra Aditya Bakti, 2014;

Kansil, Pnegantar Ilmu Hukum, Badung, Alumni, 1989; 
Manan, Hukum Ekonomi Syariah dalam Perspektif Kewenangan Peradilan Agama, Jakarta, Kencana Penadamedia Group, 2014;

Mochtar Kusumaatmadja, Pengantar Ilmu Hukum, Penerbit Alumni, 2001;

Mochtar Kusumaatmadja, Konsep-Konsep Hukum Dalam Pembangunan (Kumpulan Karya Tulis), Alumni, Bandung, 2002;

Philipus M. Hadjon, Perlindungan Hukum Bagi Rakyat di Indonesia, PT. Bina Ilmu, Surabaya, 1987;

Rachmadi Usman, Aspek-Aspek Hukum Perbankan di Indonesia, Jakarta: PT. Gramedia Pustaka Utama, 2003;

Resa Raditio, Aspek Hukum Transaksi Elektronik ,Jakarta, Graha Ilmu, 2014;

Ridwan HR, Hukum Administrasi Negara, Jakarta, Rajawali Press, 2010;

Satjipto Rahardjo, Ilmu Hukum, PT. Cipta Aditya Bakti, Bandung, 2006, , Masalah Penegakan Hukum: Suatu Tinjauan Sosiologis, Bandung Sinar Baru, 2005; Sisi-Sisi Lain dari Hukum di Indonesia, Jakarta, Kompas, 2003;

Soerjono Soekanto, Faktor-Faktor yang Mempengaruhi Penegakan Hukum, Jakarta: Rajawali Press, 2005;

\section{B. Perundang-undangan}

Undang Undang Dasar Tahun 1945

Undag-Undang No.8 Tahun 1999 tentang Perlindungan Konsumen Undang-Undang No. 21 Tahun 2012 tentang Otoritas Jasa Keuangan

Bagian Umum Penjelasan Atas Peraturan Otoritas Jasa Keuangan Nomor: 1/POJK.07/2013 tentang Perlindungan Konsumen Sektor Jasa Keuangan;

Fatwa DSN Majelis Ulama Indonesia No: 116/DSN-MUI/IX/20I7 Tentang Uang lektronik Syariah;

Fatwa DSN MUI No: 117/DSN-MUI/II/2018 Tentang Layanan Pembiayaan Berbasis Teknologi Informasi Berdasarkan Prinsip Syariah; 